\title{
Article
}

\section{Transnational Surrogacy in China: From the Perspective of Private International Law}

\author{
Yongping Xiao* \& Jue $\mathrm{Li}^{* *}$
}

Chinese courts' attitudes toward domestic surrogacy have appeared to soften and are inclined to protect the best interests of children and the legal rights of intended parents. However, many problems remain unsolved in transnational surrogacy cases, including the validity of a contract, parentage or guardianship determination, citizen conferral, and household registration. In this article, transnational surrogacy is analyzed from the perspective of private international law, particularly jurisdiction, choice of law, and recognition of foreign judgment on parental relationships and foreign public documents. In addition, some specific cases, such as transnational surrogacy for same-sex partners and transnational surrogacy without the consent of intended parents, are discussed and analyzed in detail.

Keywords: Transnational Surrogacy; Jurisdiction; Choice of Law; Public Policy; Recognition of Foreign Judgments

* Professor and Director of Institute of International Law at Wuhan University, China. LL.B. (SWUPL), LL.M. \& Ph.D. (Wuhan). ORCID: http://orcid.org/0000-0002-4788-2130. The author may be contracted at: ypxiao@vip.sina.com/Address: No 299 Bayi Road, Wuchang District, Wuhan 430072 , P.R. China. This research was supported by the special program of National Social Science Foundation (No. 18VSJ049). [国家社科基金专项: 创新 “一带一路” 国际争端解决机制问 题研究 (批准号: 18VSJ049)].

** Corresponding author. Ph.D. candidate at the Institute of International Law of Wuhan University, China. LL.B./LL.M. (Wuhan). ORCID: http://orcid.org/0000-0001-9946-3598. The author may be contacted at: jessiejura@163.com/Address: No.299 Bayi Road, Wuchang District, Wuhan 430072, P.R. China.

All websites cited in this article were last visited on February 20, 2020. 


\section{INTRODUCTION}

A brief introduction to domestic surrogacy is necessary to contextualize transnational surrogacy legal issues. Surrogacy is still in a legislative gap in China, which means it is neither expressly prohibited nor permitted by Chinese national statutes. As regard domestic surrogacy cases, the Chinese courts have so far maintained the following positions. First, medical practitioners are prohibited from performing any form of surrogacy procedure, and surrogacy advertisements are also punished by the Administration for Industry and Commerce according to Article 3(5) of the Regulation on Human Assisted Reproductive Technology of 2003 [人类辅助生殖技术管理办法] and Article 1(3)(e) of the Ethical Principles of Human Assisted Reproductive Technology and Human Sperm Banks of 2003 [人类辅助生殖技术和人类精子库伦理原则]. ${ }^{1}$ Second, surrogacy contracts, including transnational surrogacy investment contracts, surrogacy labor contracts, and business contracts, are ruled null and void because surrogacy is contrary to public order and good customs, ${ }^{2}$ violates ethics and morality, ${ }^{3}$ and runs counter to relevant policies and interests, ${ }^{4}$ as stipulated in Article 8 of the General Rules of the Civil Law of the People's Republic of China ("PRC") of 2017 (“GRCL”) [中华 人民共和国民法总则] and Article 52 of Contract Law of the PRC of 1999 (“CLC") [中华人民共和国合同法]. Finally, the legal father is the genetic father and the legal mother is the birth mother according to the blood relationship and birth criteria in Marriage Law of the PRC of 2001 (“MLC”) [中华人民共和国婚姻法].

Just like in Germany, the statutes and regulations are trying to convey Chinese deterrence and unfriendliness towards surrogacy. ${ }^{5}$ However, the Chinese courts' previous opposition to surrogacy has appeared to soften. First, Chinese citizens cannot be penalized for seeking surrogacy according to the Criminal Law of the PRC or administrational regulations. ${ }^{6}$ Second, intended parents, especially the intended mother, can get custody of the resulting child through adoption. ${ }^{7}$ Third, the exclusive authorization of the information network transmission right of a surrogacy movie ("Be a Mother") is protected by the Chinese courts. ${ }^{8}$ Finally, the design contract for a surrogacy website is enforceable and the surrogacy agency is obliged to pay the design fee according to the judgment. ${ }^{9}$

The Chinese are turning to transnational surrogacy for the following reasons. ${ }^{10}$ First, their parental relationship with the resulting children and surrogacy 
contract with surrogates and agencies are protected by foreign local laws. Second, transnational surrogacy entitles the resulting children to nationalities of specific countries, such as the US, Canada, or some other developed countries. For example, a rich couple from Shanghai decided to choose transnational surrogacy because the wife was sterile. They signed a contract with a German agency to find a beautiful and highly educated woman to provide eggs in Europe, finished the IVF surgery in Cambodia, and found an American surrogate through another agency to bear their baby. Finally, the resulting child was born in America. The total cost was about USD $183,000{ }^{11}$

However, transnational surrogacy leads to uncertain legal status among resulting children, intended parents, and surrogates. The parties involved have to face thorny problems of parenthood or guardianship confirmation, international contract disputes, and barriers to birth certificate recognition, household registration, and citizenship conferral when they travel back to China. This research article will analyze the Chinese judicial practice on transnational surrogacy in detail. Unlike common law jurisdictions, precedents in China are not binding authorities, but have a persuasive effect only when Chinese courts adjudicate similar cases involving foreign elements. ${ }^{12}$ In transnational surrogacy cases, jurisdiction, choice of law, and the recognition of foreign judgments and public documents are the three major legal issues to be discussed in the area of private international law.

\section{Jurisdiction in Transnational Surrogacy CaSes}

Jurisdiction depends on specific legal issues in transnational surrogacy cases. In practice, the issues may be classified as contract disputes and personal disputes. According to the Civil Procedure Law of the PRC of 2017 (“CPL”) [中华人民共和 国民事诉讼法], financial disputes about surrogacy contracts should be characterized as contract disputes subject to the jurisdiction of the court at the place of domicile of the defendant or where the contract was performed (Article 23 of CPL). Meanwhile, guardianship disputes should be characterized as personal disputes under the jurisdiction of the court at the place of domicile or habitual residence of the defendant (Article 21 of CPL). 


\section{A. Meizhong vs. LI}

The issue of jurisdiction is not that simple in practice. Some parties want to buy time and therefore continuously raise jurisdiction objections, especially in sensitive cases, such as transnational surrogacy. In the case of Meizhong vs. LI, both parties signed a surrogacy service contract in America, and LI paid 205,662 dollars as agreed, but Meizhong did not provide the services. LI sued Meizhong, and HE, the executive director of Meizhong, through Binhu BPC, the court of residence of the plaintiff, claimed to return USD 205,662 with interest. Binhu BPC transferred the jurisdiction to the court of the residence of HE because it had no jurisdiction according to Article 21 of CPL, which stipulates that a civil action instituted against a legal person or any other organization shall be under the jurisdiction of the court at the place of domicile of the defendant. Meizhong challenged the ruling and appealed to the Wuxi IPC, which finally affirmed the original judgment. ${ }^{13}$

First, this is absolutely a foreign-related legal issue because the habitual residence of the defendant, Meizhong Medical, is Hong Kong. The place where the contract should have been performed was the US according to Article 1 of Interpretations of the Supreme People's Court on Several Issues Concerning Application of the Law of the PRC on Choice of Law for Foreign-Related Civil Relationships I of 2012 (“ILAL”) [最高人民法院关于适用《中华人民共和国涉外民 事关系法律适用法》若干问题的解释(一)]. The people's court may determine it as a foreign-related civil relationship when the habitual residence of either party or both parties is located outside the territory of the PRC or the legal fact that leads to the establishment, change, or termination of a civil relationship happens outside the territory of the PRC.

Second, the qualified litigants were LI and Meizhong, rather than HE. The claims of LI would be rejected by the court of the residence of HE because he was not the proper defendant. According to Article 56 of the Interpretation of the Supreme People's Court on the Application of the Civil Procedure Law of the PRC of 2015 (“ICPL”) [最高人民法院关于适用《中华人民共和国民事诉讼法》的解释], where an employee of a legal person or any other organization causes harm to another person during the execution of his/her work duty, the legal person or other organization shall be a party to the case. In this case, HE was performing his duty when signing the surrogacy contract with LI because he was the executive director of Meizhong. Therefore, the only qualified defendant, in this case, should 
be Meizhong Company. Moreover, according to Article 21(2) of CPL, a civil action instituted against a legal person or any other organization shall be under the jurisdiction of the people's court at the place of domicile of the defendant. Therefore, the court of the residence of Meizhong Company in Hong Kong has jurisdiction according to CPL. In this case, however, the plaintiff might consider Hong Kong as inconvenient because it is distant and the legal system there is not the same as that in mainland China. Thus, the plaintiff finally chose to sue HE, whose residence was in Shanghai, China. ${ }^{14}$

This is a loophole in the law that parties can use to buy time, i.e., the challenge of qualified litigants and jurisdiction objection were both legal ways for buying time without fundamentally solving the problem. According to Article 119 of CPL, there will only be a formal examination when a court receives a bill of complaint and whether the defendant is the qualified litigant, which is identified as the subject of a substantive examination, will be decided only after the court accepts the case. This is an opportunistic method for lawyers to help their clients play for time, rather than solving the problem from the root. ${ }^{15}$ It sometimes leads to a private settlement, such as reaching a compromise of their own accord. A better method for LI would be to bring a lawsuit to the court at the place where the contract was signed. According to Article 265 of CPL, where an action is instituted against a defendant who has no domicile within the territory of the PRC, in a contract dispute or any other property right or interest dispute, if the contract is signed within the territory of the PRC, the people's court at the place where the contract was signed may have jurisdiction over the action.

Forum shopping is pretty common in sensitive cases, such as surrogacy or same-sex marriage, because the judgments of different jurisdictions may be completely opposite. Each party to the surrogacy contract has its reason for choosing the jurisdiction, such as preferential judgment, or convenience to start a lawsuit. ${ }^{16}$ Forum shopping and jurisdiction objection cannot be eliminated because this is a contest between the best interests of the parties involved. The conclusion can be drawn that jurisdiction conflicts during civil procedures concerning foreign affairs are, in essence, conflicts of interest between the parties concerned. Different national courts are involved in transnational surrogacy cases, and this problem can only be solved by experienced lawyers or justices. Lawyers should help their client to sue the proper defendant before a proper court. The judges should transfer the 
case to another court that has jurisdiction if possible or inform the party to institute another action to save time and judicial resources. For example, the court of the place where the contract was signed in this case. ${ }^{17}$

\section{B. Xu vs. Ouyang}

The plaintiff XU and her husband Wang were Hong Kong residents when they signed a surrogacy contract with OUYANG, whose residence is Guangzhou, China. OUYANG went to Hong Kong and delivered twin boys, who were genetically related to XU. However, OUYANG never went to Hong Kong to assist the plaintiff to become registered as the legal mother as agreed in the contract. The plaintiff sued Qingcheng BPC for confirming that the custody of the twins belonged to XU and her husband Wang and ruled that OUYANG was liable for a breach of contract and should pay RMB 30,000. However, the court refused to accept the case because the essence of this case was to confirm the parent-child relationship, which was not within the scope of a civil action according to Articles 119(4) and 154(1)(1) of CPL. ${ }^{18}$

This order is wrong on three counts. First, there was no causation between the Articles that the court cited and the decision the court made. The court's reason for refusing to accept this case was the confirmation of the parent-child relationship, which is beyond the scope of acceptance of a civil action according to Articles 119(4) and 154(1)(1) of CPL. The suit must be within the scope of acceptance of a civil action by the people's court and under the jurisdiction of the people's court where the suit is accepted when a lawsuit is brought. An order in writing must be made about the conditions leading to the refusal to accept a case. However, the scope of acceptance for a civil action is not stipulated in the abovementioned two Articles, which means that the first mistake of the court was citing the wrong Articles.

Second, the court implicitly cited the wrong Article to avoid accepting this sensitive case. The incorrectly cited Article is 357(3) of ICPL, which stipulates that the people's court must render a ruling on non-acceptance on the following situations, i.e., the party apply for judicial affirmation of a mediation agreement on validity or termination of the parent-child relationship. However, Article 357(3) should be applied only to a situation involving the judicial affirmation of a mediation agreement, which obviously is not in this case since this case was totally independent of mediation and the confirmation of custody does not comprise an 
affirmation of the parent-child relationship.

Third, the court deliberately ignored the plaintiff's claim for compensation for losses, which is obviously a contract dispute and should be in the scope of acceptance for a civil action. However, the court did not mention this application in the order at all and therefore ran counter to the principle of prohibition of the denial of justice. ${ }^{19}$

To reduce the uncertainty of jurisdiction in transnational surrogacy cases, some international organizations exist that work on the jurisdiction issue by referring to parentage or guardianship determination. For example, HCCH (Hague Conference on Private International Law) focused on indirect jurisdiction and then considered if those connecting factors could be used to determine the direct rules of jurisdiction. In terms of indirect jurisdiction, the state where the decision was issued should be the place of the habitual residence of the respondent or the place of the habitual residence of the person whose parentage is the subject of the proceedings. ${ }^{20}$ However, a broad list of indirect jurisdiction grounds may increase the potential for forum shopping and lead to limping relationships. A few countries, such as Hungary, consider that domestic courts have exclusive jurisdiction over legal relationships between Hungarian nationals to forefend this situation. $^{21}$

It is not feasible to develop a convention on the jurisdiction of personal disputes at present because the attitude toward surrogacy and regulation of jurisdiction varies from country to country. It is rather proper for Chinese legislators to make special jurisdiction regulations on parentage determination as follows. First, actions instituted for disputes arising from the determination of parentage or guardianship between Chinese citizens should be under the jurisdiction of the people's courts of the PRC. Second, actions instituted for disputes arising from the determination of a personal relationship between Chinese citizens and foreigners should be under the jurisdiction of the people's courts of the PRC or the habitual residence or the birthplace of the child that favors the rights and interests of the resulting child. Third, actions instituted for disputes arising from the determination of a personal relationship between foreigners can be refused or transferred according to forum convenience. ${ }^{22}$ 


\section{Choice of Law in Transnational Surrogacy Cases}

Before 2010, only a few choices of law rules were scattered throughout Chinese laws, which were unsystematic and inconsistent. In 2010, the Law of the PRC on Application of Laws to Foreign-Related Civil Relations of 2010 (“LAL”) [中华人 民共和国涉外民事关系法律适用法] was enacted as a national statute, which marked a significant progression in Chinese private international law history. LAL stipulates the basic choice of law rules in contract and family issues. Intended parents may not consider the legal issue of choice of law at all; they believe that the law of the birth place of the child will always apply. ${ }^{23}$ In judicial practice, however, the process of characterization and choice of law were always omitted in transnational surrogacy cases, which are discussed in detail in the following section.

\section{A. Xu vs. Meijia}

The plaintiffs Xu and her husband Chen signed a contract with Meijia Company for gestational surrogacy with Chen's gamete and an egg donor. The surrogacy would be enforced in America, whose total cost was one million RMB. Even after the plaintiffs made the full payment, however, Meijia did not provide an embryo transplantation service and was unable to find the proper surrogate for the plaintiffs as agreed. Both parties agreed on the dissolution of the contract and for Meijia to return the rest of RMB 280,000 and interest to the plaintiffs. However, Meijia did not pay the debt on time, and the plaintiffs sued them in court, claiming the return of RMB 280,000 with interest. The court held this surrogacy contract null and void because it violated public order and good morals according to Article 52 of CLC, and Meijia returned RMB 280,000 to the plaintiffs because it respected the autonomy of both parties. ${ }^{24}$

There were two basic legal issue from a private international law perspective that remained unsolved in this case: characterization and choice of law. This case should have been characterized as an international case according to Article 1 of ILAL because the surrogacy contract would be mainly enforced in America. Therefore, applicable should have been the law of Meijia's habitual residence because its performance of obligations best reflected the characteristics of the contract and CLC had the most significant relationship with the contract according 
to Article 41 of LAL. Seemingly, Article 52 of CLC finally applied to this case. However, the process of characterization detailing the choice of law should not be ignored or missing. The justice should have made the decision from the legal perspective of private international law in international disputes.

Apart from the legal issue of the choice of law, the plaintiffs should be paid by the defendant more than RMB 280,000 as claimed. The plaintiffs should have instituted an action directly to the court without a private settlement agreement and claim for the amount of RMB 280,000 plus at least half of RMB 720,000 as in the following case of Sears vs. Sun. Both parties were at fault when signing this illegal surrogacy contract, and therefore both should bear their respective liabilities according to Article 58 of CLC. According to the principle of "no claim, no trial," however, this was not the fault of the justice, but the lawyers in this case. The plaintiffs could have taken better legal advice, and the remuneration paid might have recovered much more if they had a more professional lawyer. Therefore, the professional lawyers are needed in the field of surrogacy, especially transnational surrogacy, for helping the parties for better understanding on the risks during surrogacy arrangements, although this is a tough work since surrogacy was not yet lawful in China. ${ }^{25}$

\section{B. GAO vs. Meijia}

Similar to Xu vs. Meijia, in the case of GAO vs. Meijia, both parties signed a contract in January 2016 where GAO gave Meijia Co. RMB 50,000 and then became responsible in part of the company's business, mostly services delivering babies in the US and transnational surrogacy. GAO sued and told the court that the contract was invalid because surrogacy was forbidden in China. The court ruled the contract invalid because the business of surrogacy was deemed contrary to public order and social morality in China and the National Health Commission and 12 departments had made a work plan for carrying out a special action against surrogacy nationwide. ${ }^{26}$

Something had also gone terribly wrong in this case, at least in the application of the legal process. This contract was about delivering a surrogacy service in America, which clearly involved foreign actors. Hence, the applicable law should have been dealt in accordance with the choice of law rules in LAL. However, the justice directly applied the General Principles of the Civil Law of the PRC of 
2009 [中华人民共和国民法通则] and the regulations of China without considering the LAL in this case. The correct procedure for the application of law should be as follows. First, this case was characterized as a contract dispute with foreign elements based on Article 1 of ILAL, which meant that the applicable law should have been the law of the defendant's residence or the place that had the most relationship with this case according to Article 41 of LAL. Second, the court could have used its right to discretion to choose which law of either China or the US should be applied to this case because the defendant's residence was Beijing, China, and the contents of this contract refer to the delivery of a surrogacy service in America.

The outcomes of the two cases mentioned above could have been completely different if the court had applied the Contract Law of America because surrogacy is lawful in quite a few states of the US. As this entire procedure was omitted and the judges directly applied the CLC, however, the Chinese justice lacked professional skills in the PIL area.

\section{Sears vs. Sun}

In the case Sears Ltd. vs. Sun, Sun and Sears signed a surrogacy contract in America in March 2017. Sun paid RMB 150,000 to Sears in April 2017, but Sears, as the surrogacy agency, did not provide the surrogacy service as agreed. Sun sued Guangzhou Qianhai Shenzhen BPC for ruling the contract null and void, requesting Sears to return the total cost of RMB 150,000 with the interest. The first-instance court ruled the surrogacy contract null and void, and Sears was requested to return 100,000 RMB to Sun. Sears appealed to Guangdong Shenzhen IPC, but the second-instance court affirmed the original judgment. ${ }^{27}$

Two legal issues should be explored in this case. The first was the application of the law. Unlike GAO vs. Meijia Ltd, this case was initially characterized as a foreign-related case by the first-instance court because one of the locations of the performance of the contract was in America. Both courts applied Article 41 of LAL in this case to choose CLC as the applicable law to this transnational surrogacy contract dispute, because the place of the most significant relationship was China, i.e., the habitual residence of the parties, the place of signing the contract, and part of the performance of the contract were all in China. ${ }^{28}$

The second issue was the sum of the returned money with interest. As in 
domestic surrogacy cases, the contract was ruled null and void according to Article 52 of CLC. Therefore, after a contract becomes invalid, any property obtained under the contract should be returned. In this case, both parties should bear their respective liabilities if they were both at fault, according to Article 58 of CLC. Unlike the abovementioned Xu vs. Meijia, the court considered that the loss was caused by both parties in this case because they signed the contract with full knowledge that surrogacy was not lawful in China. Therefore, each party should bear its corresponding liability. The court considered that RMB 50,000 for providing visa application services, ticket purchasing, hotel booking, and America's hospital fee was a reasonable cost. Therefore, Sears only needed to return the rest of RMB 100,000 to Sun without interest.

\section{Jiang vs. Ren}

Jiang and Ren got married in 2001 and had a daughter named Jiang A via surrogacy in America in 2014. Jiang A traveled back from America to China for a month and then moved to Cyprus and lived with Jiang and her grandparents, which meant Jiang A did not live with Ren for a long time. The custody of Jiang A was awarded to Jiang by the court of Cyprus. Jiang sued for divorce and custody of Jiang A and requested Ren to pay RMB 5,000 per month toward the cost of the child's upbringing. The court approved the divorce and awarded custody to Jiang in the best interest of the child and ordered Ren to pay RMB 2,000 per month for child support. $^{29}$

The first legal issue in this case was the characterization and choice of law, which were already discussed in detail in the cases mentioned above. The second legal issue was the custody dispute, which was a bit complicated. First, the court did not mention the surrogate at all when deciding the custody of Jiang A, although she was the legal mother according to MLC. Second, the court awarded custody to Jiang, the legal father, who was genetically related to Jiang A, while ruling Ren to pay RMB 2,000 per month. This meant that the court considered Jiang A as a child born out of wedlock between Jiang and Ren, although she was born under a surrogacy arrangement, and Ren should have been responsible for bringing her up. Third, the reason for awarding the custody to Jiang was the best interest of child, because Jiang was a better guardian as he had lived with Jiang A for more than 3 years in Cyprus and had a higher income to provide a better living 
conditions. $^{30}$

Finally, we conclude that Article 25 of LAL should be applied to choose the law applicable to disputes in transnational surrogacy cases, although it has sometimes been ignored by justices in sensitive cases, such as transnational surrogacy. However, Article 25 of LAL is not enough clear for the application to transnational surrogacy cases for parenthood identification as follows. First, whether the "personal relationship of parents and children" includes establishing or recognizing parenthood is open to debate because there is a preliminary question required to clarify who is the parent or child to determine their relationship. Second, the expression of the "mutual habitual residence of parents and children" as connecting factors may lead to a vicious circle as the father and mother had not been determined at the time of applying conflict rules. The expression of 'father,' 'mother,' or 'parents' in connecting factors should be avoided ${ }^{31}$ and replaced by lex fori. ${ }^{32}$ Third, it is not enough to protect the best interests of children by merely stipulating that it is beneficial to protect the rights of the weak because there are many weak parties in transnational surrogacy cases: resulting children, surrogates, or even intended parents. Therefore, it is necessary to clearly stipulate the principle of "the best interests of the children" as a soft connecting factor. It is both the value orientation of Chinese courts and an international trend to prioritize the best interests of children as the first consideration. ${ }^{33}$

However, even if the court correctly characterized the legal issue as an international dispute, CLC could not be applied for the following reasons. First, the court may decide to apply the law of the most significant relationship, which is CLC, and apply it to this case according to Article 41 of LAL. Second, evasion of the law is illegal in China and the produced connecting factors in transnational surrogacy arrangements are invalid according to Article 11 of ILAL. ${ }^{34}$

In addition, there are many scholars, experts, and international organizations working on international conventions about choice of law rules. ${ }^{35}$ An international agreement will be very helpful but hard to achieve in the short term because the applicable laws and connecting factors and the attitudes to surrogacy in each country differ in many ways. Therefore, a better way to deal with the problem is to make more specific domestic rules. There are three legislative methods we can borrow for reference. First, more specific regulations about transnational surrogacy should be formulated, with connecting factors that can be either the location of 
surrogacy or the birthplace of the resulting child, or lex fori. Second, broader statutes about "parental relationships by ART" are a more sufficient and practical solution for transnational surrogacy since these statutes are not only helpful in transnational surrogacy cases, but also can be used to deal with other parenthood relationships with children born under ART. Third, an even broader regulation about the transnational parental relationship between parents and illegitimate children should be made. ${ }^{36}$

\section{Recognition of Parentage in Transnational Surrogacy Arrangements}

There are two kinds of recognition for foreign parentage: foreign judgments and foreign public documents. These categories were thoroughly discussed in the $\mathrm{HCCH}$ conference from 2014 to 2020, where the experts suggested that the international instrument should focus on the second category. ${ }^{37}$ Legislation on the recognition of foreign judgments and documents is discussed separately in this section. $\mathrm{HCCH}$ has been committed to facilitating the formulation of an internationally binding instrument on transnational surrogacy. It is very hard work to draft an international convention on the recognition of parentage in transnational surrogacy arrangements because there is a considerable discrepancy between domestic family law and public order issues between countries. ${ }^{38}$

\section{A. Recognition of Foreign Judgments}

Not a single case was reported by Chinese courts that the Chinese applied for recognition of foreign judgments, which had confirmed their parenting relationship with resulting children. For example, in the case of Jiang vs. Ren, Jiang instituted a new action in the Chinese court requesting them to award him custody of Jiang A, although custody has already been awarded to Jiang by the court of Cyprus. ${ }^{39}$ Therefore, this part discussed the recognition procedure hypothetically when a foreign judgment on parentage in a transnational surrogacy arrangement came to the Chinese courts.

Some Chinese private international lawyers have conducted valuable research on the recognition of parentage in transnational surrogacy cases. ${ }^{40}$ Most scholars 
considered that the recognition of foreign judgments violates Chinese public policy because surrogacy contravenes the fundamental principles of public order and good customs in GRCL and CLC. ${ }^{41}$ According to Article 282 of CPL, a foreign judgment of parentage in surrogacy arrangements will only be recognized if it neither contradicted the primary principles of the law of the PRC, nor violated state sovereignty and security and the social and public interest of the PRC.

To be more specific, public order and good customs in GRCL reflect the primary principles of the law and the social and public interest of the PRC. As surrogacy contracts run counter to GRCL, CLC, and CPL, they cannot be recognized and enforced in China. However, a judgment of parentage is not the same legal issue as a surrogacy contract dispute. It means that recognizing the intended parents as legal parents or guardians may not violate public order in China because they are recognized as legal parents considering a blood relationship, adoption, or the principle of the best interest of the child, rather than the surrogacy agreement. Moreover, when the recognition of parentage in a foreign judgment comes before a court as a preliminary question only, this relationship should be recognized in a limited sense because it is better to solve the major issue and protect the legal rights of all parties. ${ }^{42}$

Two barriers to the recognition of foreign judgments remain according to Article 282 of CPL, which covers international treaties and reciprocity. First, there should be an international treaty between the PRC and the country that made the judgment. Second, the principle of reciprocity is necessary if there is no bilateral treaty between China and the applicant country, except if the party applies to the people's court for the recognition of an effective divorce judgment rendered by a foreign court. This exception can be extended to parentage judgments for the following reasons. First, it has a weak connection with public interest. Second, it is beneficial to the stability of the relationship between the intended parents and resulting children. Third, it follows the principle of the best interest of the child, which has become the consensus of all countries in the world, because refusing to recognize a foreign judgment will leave the child's status, rights, and abilities in limbo. ${ }^{43}$

\section{B. Recognition of Foreign Public Documents}

By contrast, the recognition of foreign public documents is more feasible in 
practice. The Convention Abolishing the Requirement of Legalization for Foreign Public Documents (hereinafter Apostille Convention) is the best law to apply to the recognition of public documents, such as a birth certificate. As China is not a member of the Apostille Convention yet, however, foreign public documents need to go through the following steps when applying for recognition in China. First, the party should entrust an international notary to notarize the birth certificate registered abroad. Second, the notarized birth certificate must be sent to the foreign ministry for certification. Third, the birth certificate certified by the foreign affairs department must be sent to the Chinese embassy or consulate in the country for authentication. Finally, the recognized legal document should be sent back for use. If China were a member of the Apostille Convention, then the second step could be omitted. ${ }^{44}$

In brief, the legal parentage is more likely to be recognized through a public document rather than foreign judicial decisions. However, the experts of $\mathrm{HCCH}$ consider that a public document, such as a birth certificate, does not establish legal parentage but only operates as a rebuttable evidence of legal parentage, unless and until it is successfully contested. In Germany, for example, the foreign birth certificates was not recognized since it was not the enforceable judgments which could be recognized by Germany courts and surrogacy violated public policy. ${ }^{45}$ In China, however, an authenticated birth certificate cannot serve as the legal parentage certificate because it can easily be rebutted if the intended mother does not have a blood relationship with the child. Therefore, the real effect of the recognition of a foreign birth certificate of a surrogacy child is extremely limited.

\section{Transnational Surrogacy for Same-Sex Partners}

It would take an armchair strategist to figure out the parental relationship between same-sex couples and the resulting children because same-sex marriage and surrogacy are both illegal in China. However, it is not uncommon for Chinese same-sex couples to have their own children via transnational surrogacy, which has been discussed at length in some countries. ${ }^{46}$ There are two major issues for Chinese same-sex couples who have their babies via surrogacy: deciding the "legal parentage" of the homosexual male partners and health insurance coverage. 


\section{A. Zhao vs. Jiang}

There are some differences between lesbian and gay lovers because lesbians can deliver babies by themselves but gays cannot. Zhao and Jiang are Chinese lesbian lovers, who went to America for their baby by ART and IVF surgery in 2016. The embryo, which was genetically related to Zhao and the sperm donor, was transferred to the womb of Jiang, and the girl was delivered in America in February 2017. Meanwhile, the lovers registered a domestic partnership in California in January 2017 and signed the agreement on the dissolution of domestic partnership in the US consulate in Shanghai in November 2017. Jiang claimed that she was the surrogate, but the court did not confirm because both parties registered a domestic partnership and they were the parents of the girl on the birth certificate. ${ }^{47}$

This is not a typical surrogacy case, whose major legal issue concerned the partitioning of property acquired by the parties during their period of cohabitation. The court considered that they were actually in a cohabiting relationship although same-sex marriage or partnership were not yet lawful in China and supported Jiang's claim for the equal partitioning of property. ${ }^{48}$ It could be at least inferred from the judgment that their relationship did not break the law and the courts were inclined to protect the legal rights of same-sex partners and prevent one samesex partner from evading family responsibilities. Therefore, the same-sex partners were not subject to greater disadvantages than heterosexual cohabitants in judicial practice regarding the partitioning of properties.

However, the lesbian partners would still face other problems with transnational surrogacy arrangements. For example, if same-sex partners had their child via transnational surrogacy and then traveled back to China, then the identification of the parents of the resulting child would be a thorny problem. There are three women in this relationship: one member of the lesbian couple is genetically related to the child, her spouse, and the surrogate, who actually delivered the child. According to Chinese law, the surrogate should be the legal mother, but the identification of the legal father is still questionable. This is a double dilemma for Chinese same-sex partners who have children via transnational surrogacy. One suggestion is turning to custody determination. This option has less strict limitations than parentage because many individuals or organizations that are willing to bear the responsibility of guardianship can be a guardian, provided that the individual or organization obtains approval 
from the neighborhood or village committee in the place of the minor's residence or the civil affairs administrative department. ${ }^{49}$

\section{B. A.G.R. vs. D.R.H.}

Similar to lesbian surrogacy, the status of a legal father is unique in the situation of gay surrogacy because there are two intended fathers, but no intended mother. In the case of A.G.R. vs. D.R.H., a legally married gay couple signed a surrogacy contract with a surrogate. The surrogate delivered twin girls as agreed but changed her mind five months later and sued to be the legal mother of the girl. The court finally supported the surrogate's application and recognized her as the legal mother of the twin girls. ${ }^{50}$ The only legal father between the gay couple was the partner who had a biological relationship with the child, whereas the other partner had no legal entitlement to be recognized as a father except adoption, which also poses risks.

A suggestion would be to use the pure intent test to decide the legal parents and avoid the dilemma entailed with the child calling the biological father as 'father' and the surrogate as 'mother,' who does not live with them and has no contact with the legal father. Meanwhile, the lawful spouse of the legal father has no legal relationship with his partner's children. Therefore, using the term 'parents' to substitute "father and mother" respects the gay couple's legal right to parentage and eradicates discrimination from the statute. Finally, in China's current legal situation, it is more flexible and feasible for the baby to be settled permanently with the same-sex partner who is genetically related to the child, whereas the other does not have legal custody since he is not a lawful spouse of the legal father and has no genetic relationship with the child.

\section{Uddoh vs. United Healthcare}

Not only legislation - and jurisdiction-based obstacles but also problems are posed by family economic status and health insurance coverage. If heterosexual couples were infertile, then their medical expenses referring to IVF surgery, assisted hatching, and embryo banking could all be covered by their health insurance. In this case, Humphrey O. Uddoh and his male partner Plamen Koev wanted a baby via surrogacy, but their insurance company United Healthcare refused to pay their bill. Therefore, the gay couple sued the court for USD 150,000 medical costs and USD 4,000,000 of damages. Finally, the court dismissed their application because 
there was no discrimination toward the applicants in this case and their surgery went beyond their insurance coverage. ${ }^{51}$

In real life, however, an insurance covering surgery or medical technology is not applied to gay couples because their biggest obstacle to having babies is not infertility but their physiological structure. Possibly, as the district court held, this is not discrimination toward gays, but the rights of gay couples to health insurance for fertility problems, which does not protect the right of heterosexual couples.

\section{Transnational Surrogacy without Consent}

Life is always more unimaginable and intriguing than made-up stories. Legal issues of ownership and the right to the use of embryos are preliminary questions of parentage determination in cases of surrogacy for the decedents or without the consent of an "intended father."

\section{A. N Shen vs. Gulou Hospital}

In the case of $N$ Shen vs. Nanjing Gulou Hospital (hereinafter Gulou Hospital), J Shen, son of N Shen and Shao, and X Liu, daughter of F Liu and Hu, got married in 2010. In August 2012, J Shen and X Liu performed IVF to assist with pregnancy in Gulou Hospital. Four fertilized eggs developed into blastocysts, and the couple agreed to cryopreserve them at Gulou Hospital for one year on September 3, 2012. Unfortunately, X Liu and J Shen died in a car accident on March 25, 2013. The plaintiff, N Shen, Shao, F Liu, and Hu instituted an action against Gulou Hospital to the court for the right of supervision and disposal of the four embryos. The first-instance court dismissed the plaintiff's claim, but the second-instance court reversed the judgment and ruled that the four frozen embryos should be jointly supervised and disposed of by the four appellants in September 2014. After two years of navigating a lot of red tape, the four embryos were finally removed from the hospital in 2016. They were transferred to Laos, and a Laotian surrogate successfully delivered a baby in Guangzhou in December $2017^{52}$

There are five thorny legal issues in this case. The first issue is whether the 'grandparents' had the right to give birth to their 'grandchildren' via surrogacy. 
This case is akin to a case that happened in Venezuela when a woman requested a clinical center to give her a sample of her dead husband's sperm to carry out an IVF process. The clinical center refused to give it to the woman because there was no consent from her deceased husband. Finally, the Supreme Tribunal of Justice granted the remedy and recognized the right to procreation in favor of the consolidation and welfare of the family. ${ }^{53}$ Likewise, ART surgery is legal for infertile couples in China because the judicial interpretation of the supreme people's court regulated that if both members of the couple agreed to artificial insemination, then children born under this surgery should be seen as legitimate children of this couple, even if there was a sperm or egg donor. ${ }^{54}$ For the family welfare, after the young couple unluckily died off, the court finally ruled that the embryos could be disposed of by the four applicants, which means that the applicants had the right of disposal, including finding a surrogate to bear their 'grandchildren.'

The second issue is to clarify whether the embryos were the object of an inheritance right. The answer is negative. According to Article 3 of Law of Succession of the PRC of 1985 (“LSC”) [中华人民共和国继承法], the estate denotes the lawful property of a citizen owned by him personally at the time of his death, consisting of his income, houses, savings, articles of everyday use, forest trees, livestock and poultry, cultural objects, books, reference materials, means of production lawfully owned by him, property rights pertaining to copyright and patent rights, and other lawful properties. Embryos are not one of the abovementioned estates. It is even difficult to judge whether an embryo is a lawful 'property' or not, as special objects with the potential to develop into life cannot be transferred or inherited arbitrarily, such as ordinary things. The couple had passed away, and their aim of having children through ART was no longer possible. However, the second-instance court did not mention a single word about inheritance in the judgment. ${ }^{55}$ It means that the court characterized this case as a normal ownership dispute, rather than a succession dispute, because the applicants claimed the right of supervision and disposal, rather than the succession of the four embryos. The court's decision for the embryos to be disposed by the four applicants was derived by considering moral principles in the interest of the embryos, rather than on the basis of legal succession rights.

The third issue is to identify the owner and possessor of the embryos. 
These embryos should belong to the four grandparents. Under contract law, Gulou Hospital could not unilaterally dispose the involved embryos, although the contract could not be continued due to the unforeseeable and undesirable situation of the deceased parties. From the perspective of the relevant rights of the embryos, it is more reasonable to award the ownership to the four grandparents. First, the embryos contained the genetic information of two families, and both parents were closely related to the embryo in life and ethics. Second, the supervision and disposal of the embryos by both sets of grandparents could also alleviate the pain of losing the only child for both families because the embryos were the last surviving blood for continuation. From the perspective of special interest protection, the court held that the embryos were in a state of transitional existence between a human and an object, which had the potential of becoming life. Therefore, the embryos had a higher moral status than inanimate objects and should be specially respected and protected. ${ }^{56}$

The fourth issue was the cross-border transportation of the four liquid-nitrogenfrozen embryos. Embryos are not permitted to be consigned by airlines according to Article 9 of Regulations of the PRC on Administration of Human Genetic Resources [《中华人民共和国人类遗传资源管理条例》]. The collection, preservation, utilization, or supply abroad of human genetic resources from China must conform to the principle of ethics and be subject to ethical review in accordance with the abovementioned regulations. To be more specific, this process must respect the privacy of the providers of human genetic resources, obtain their informed consent in advance, and protect their lawful rights and interests. In this case, $\mathrm{N}$ Shen delivered the liquid nitrogen tank to Laos via self-driving and placed it in the trunk of the car. Intended parents in transnational surrogacy arrangements would normally go to the Chinese embassy for travel documents for the resulting child according to the result of the paternity test, which was impossible in this case because the intended parents were both dead. Therefore, the surrogate traveled to Guangzhou, China, to deliver the baby, prior to the legal issue of determining the custody of the resulting child.

The final issue was identifying the nationality and custody of the resulting child. According to Article 4 of the Nationality Law of the PRC of 1980 ("NLC"), any person born in China whose parents are both Chinese nationals or one of whose parents is a Chinese national shall have Chinese nationality. Therefore, 
the nationality of the resulting child should be Chinese because she was born in Guangzhou, China, and the legal father J Shen was Chinese. It is both the right and obligation of the grandparents to be the guardian of the minors if their parents are dead. Paternal or maternal grandparents have the competence to be a guardian if the parents of a minor are dead or lack the competence to be a guardian according to Article 27 of GRCL of 2009. Moreover, grandparents and maternal grandparents who can afford to bring their grandchildren or maternal grandchildren who are minors and whose parents are dead or have no means to bring them up can be guardians according to Article 28 of MLC. However, this is not a perfect solution, although there could hardly be any perfect solution in this unfortunate case. The resulting child was born an orphan, which did not properly protect the best interest of the child but only satisfied the emotional needs of the four grandparents.

\section{B. Wang vs. Zhang}

Wang is a Hong Kong SAR resident and fell in love and lived with Zhang together in 2000. They had a girl "A Wang" via surrogacy, who was genetically related to the egg donor and Zhang because Wang was deemed infertile in 2001, and another girl "B Wang" via ART by Wang herself in 2003. The dissolution of their cohabitation relationship was permitted by the court in 2003, and Wang was awarded the custody of A Wang and B Wang. Wang had a boy "C Wang" via surrogacy with the original embryo without the consent of Zhang in 2008 following the dissolution of cohabitation. Wang instituted an action to Tianhe BPC that Zhang should be responsible for raising $C$ Wang, which was rejected because the birth of $\mathrm{C}$ Wang infringed Zhang's right of reproductive choice and violated China's family planning policy and principles of reproductive ethics. ${ }^{57}$

There were two legal issues to be explored in this case. The first legal issue was the determination of the legal father of $\mathrm{C}$ Wang. In this case, Zhang could be regarded as a sperm donor, who has neither rights nor responsibilities for the born offspring, including raising, custody, and succession, because there is no legal relationship between the donor and the resulting child. Therefore, Zhang, as the genetic father of C Wang, was neither the legal father, nor needed to take any responsibility. The legal mother was Wang, and the legal father should be her husband, who could regard the child as a legitimate child or stepchild, as in the 
case of Mrs. Chen vs. Mr. Luo. ${ }^{58}$

The second issue pertains to the right to the disposal of the embryos. According to the Law of the PRC on Population and Family Planning of 2015 [中华人民共和 国人口与计划生育法], Chinese citizens have the right to reproduction, which meant that Zhang also had the right to dispose of the original embryo. Wang privately turning to surrogacy with the original embryo without Zang's consent obviously violated his right to reproduction. Zhang had the basic right not to be forced to be a father, although Zhang was the genetic father of C Wang. A similar question arises about the right to the disposal of embryos as in the case of the dead couple mentioned above. Both embryos were disposed of by others without their consent. It is different that the couple could not give their consent but Zhang could. However, what if the couple did not agree with surrogacy, even it was the last and best hope for their parents?

In the two cases about the disposal of embryos mentioned above, we find some differences. First, as the owner of the embryos, the young couple were dead, whereas Zhang was alive, which meant that only Zhang could give consent. Second, the four applicants in Mr. N Shen vs. Gulou Hospital had the strongest genetic relationship in the world with the embryos, whereas Wang had no genetic relationship with the original embryo. Third, the four applicants only produced offspring but did not ask the genetic parents to take responsibility as Wang requested. Fourth, the four applicants claimed the right of disposal of the embryos, rather than guardianship or parentage of the resulting child. It can be inferred from these cases that the Chinese courts' attitudes toward surrogacy comprise reasonable constraints and appropriate disclosure.

\section{Conclusion}

From a jurisdictional perspective, Chinese courts are inclined to refuse to accept sensitive cases, such as transnational surrogacy disputes, due to the lack of jurisdiction. Meanwhile, the lawyers of Chinese parties sometimes use the loophole of Article 119 of CPL to raise a jurisdiction objection and buy time, which wastes judicial resources, but never solves the problem.

In terms of choice of law, Chinese justices have sometimes omitted the 
procedure of characterization and choice of law and directly apply lex fori (CLC and MLC) in foreign-related civil cases. Justices should make judgments according to the legal thinking of PIL in international disputes. However, Chinese justices may still choose lex fori according to the principle of the most significant relationship in LAL. Moreover, even if the applicable law is a foreign law in a transnational surrogacy case, the effect of applicable foreign law does not occur according to ILAL because these cases involve an evasion of the law and the intentionally created connecting factor is not valid.

When deciding on foreign surrogacy parental relationships, Chinese parties are inclined to institute new action in China, although a foreign court may have already made a judgment on guardianship of the resulting child. Next, when determining the recognition of foreign public documents, a lot of red tape is involved in the process of the mutual authentication of public documents because China is not a member of the Apostille Convention. Hence, the Chinese embassy and notary office can be obstacles in the notarization and authentication of documents because surrogacy is not yet lawful in China.

It is more difficult for Chinese justices to decide the legal parents of resulting children in transnational surrogacy cases involving same-sex couples because neither surrogacy nor a same-sex partnership is lawful in China and same-sex partners have no legal basis to be parents. Finally, when identifying the legal issues of transnational surrogacy without the consent of intended parents, two different conditions must be considered. First, in the case of grandparents turning to transnational surrogacy to bear a child of dead intended parents, there are many legal issues to be solved, such as the transnational transportation of embryos, documents for entering China, guardianship determination, and household registration. Second, a private surrogacy without the consent of the intended father can obviously be recognized as violating his right to reproduction.

Finally, banning surrogacy is definitely not the best way to protect parties' interests and regulate the surrogacy market because there is a real demand for surrogacy in China. Innocent resulting children do not choose to be born, but they have to face the situation of statelessness and uncertain parentage when traveling back to China. Many factors contribute to the present unsatisfactory situation, and surrogacy is more of a problem of morality and ethics than law. Chinese ideology is becoming more open-minded from one generation to the next, and the real 
demand and social reality of surrogacy will become more acceptable in the future when surrogacy cases can be spontaneously solved.

\section{REFERENCES}

1. Wuhan Qingtian Consulting co., LTD vs. Industrial and commercial administration bureau of Wuhan East Lake New Technology Development Zone, Hubei Wuhan IPC, (2018) E 01 Xingzhong 898 [(2018) 鄂01行终898号]. Wuhan Xintaifu Biomedical technology co. LTD vs. Industrial and commercial administration bureau of Wuhan East Lake New Technology Development Zone, Hubei Wuhan IPC, (2018) E 01 Xingzhong 899 [(2018) 鄂01行终899号]. Wuhan Administration of Industry and Commerce vs. Zhongtouhesheng Medical Investment Co. Ltd., Hubei Wuhan Wuchang BPC, (2015) E Jianghan Xing Feishen 00049 [(2015) 鄂江汉行非审字第00049号]. < available only in Chinese>.

2. Danna SHI vs. Xiaotong ZHANG, Heilongjiang Haerbin IPC, (2018) Hei 01 Min Zhong 4587 [(2018) 黑01民终4587号]. Guodong Jin vs. Zhengpei Yang \& Guangzhou Moden Hospital co. LTD., Guangdong Guangzhou Tianhe BPC, (2018) Yue0106 Min Chu 12551 [(2018) 粤0106民初12551号]. Shenzhen sears international business consulting co., LTD vs. Yan SUN, Guangzhou Shenzhen IPC, (2018) Yue 03 Min Zhong 9212 [(2018) 粤03民 终9212号]. Mo LIN vs. Luping FENG, Shandong Jinan IPC, (2018) 01 Min Zhong 7948 [(2018) 鲁01民终7948号]. Jiahong WANG vs. Gonghua RUAN, Shanghai No.2 IPC, (2016) Hu Min Zhong 9572 [(2016) 沪02民终9572号]. Han LIU vs. Tiantian LI, Ligang ZHAO, Henan Linchuan BPC, (2015) Lin Min Chu 923 [(2015) 临民二初字第923号]. $<$ available only in Chinese>.

3. Yuantao LIU vs. Shenzhen Jennie Biotechnology co. LTD, Guangdong Shenzhen IPC, (2018) Yue 03 Min Zhong 22336 [(2018) 粤03民终22336号]. Shaohong XING \& Jie GU vs. Tao LIANG, Hubei Wuhan Jiangxia BPC, (2017) E 0115 Min Chu 3409 [(2017) 鄂 0115民初3409号].<available only in Chinese>.

4. Xiaoxia LIN vs. Ling LIU, Guangdong Shenzhen Baoan BPC, (2018) Yue 0306 Min Chu 13309 [(2018) 粤0306民初13309号]. Zhiwei LUO vs. Guohao ZHONG, Guangdong Qingyuan IPC, (2017) Yue18 Min ZHong 2766 [(2017) 粤18民终2766号]. Li GAO vs. Meijia Co \& Jie LI, Shandong Dezhou IPC, (2017) Lu14 Min Zhong 1863 [(2017) 鲁14 民终1863号]. <available only in Chinese>.

5. P. Gerber \& K. O'Byrne, Souls in the House of Tomorrow: The rights of Children Born via Surrogacy, in Surroagcy, Law and Human Rights 185 (P. Gerber \& K. O’Byrne eds., 2015). 
6. Z. Huo, Report of The People's Republic of China, in Transnational Surrogacy Arrangements: Legal Regulation at the International Level 94 (K. Trimmings \& P. Beaumont eds., 2013).

7. A ZHAO vs. B ZHAO, Shanghai 02 IPC, (2017) Hu Min Zhong 7243 [(2017) 沪02民终 7243 号]. Ying CHEN vs. Ronggeng LUO, Shanghai 01 IPC, (2015) Hu 01 Zhong Shao Min Zhong 56 [(2015) 沪一中少民终字第56号]. Zongqiong WANG vs. Xiwei ZHANG, Guangzhou Tianhe BPC, (2011) Sui Tian Fa Shao Min Chu 128 [(2011) 穗天法少民初字 第128号]. <available only in Chinese>.

8. Shenzhen Xunlei Network Technology co., LTD. vs. Guangzhou Pearl River Digital Group co., LTD, Guangzhou Yuexiu BPC, (2014) Sui Yue Fa Zhi Min Chu Zi 809 [(2014) 穗越法知民初字第809号]. <available only in Chinese>.

9. Shanghai Manlang Marketing planning co., LTD. vs. Shanghai Meiyun business consulting co., LTD, Shanghai Hongkou BPC, (2015) Hong Min2 Chu 1036 [(2015) 虹民二(商)初字 第1036号]. < available only in Chinese>.

10. M. Greco, The Status of Children Arising from Inter-Country Surrogacy Arrangements 54 (2016).

11. See Understanding the Costs of Surrogacy, available at https://www.circlesurrogacy.com/ parents/how-it-works/programs-costs?gclid=EAIaIQobChMIrPCDounu5wIVRmoqCh3L aw2QEAAYASAAEgLdFPD_BwE.

12. M. Law, Conflict of Laws, in Chinese LAw 725 (W. Guiguo \& J. Mo eds., 1999).

13. LI Yongmei vs. HE Wei, Wuxi Binhu BPC, (2016) Su0211 Minchu 1572 [(2016) 苏0211 民初1572号]. LI Yongmei vs. Meizhong International Medical co. LTD., Wuxi IMC, (2017) Su02 MinXia Zhong 791 [(2017) 苏02民辖终791号].<available only in Chinese>.

14. Y. Chen, How to solve the dilemma of parallel litigation between mainland and Hong Kong: From the perspective of a parallel litigation on letter of credit fraud in mainland which Hong Kong high court heard [如何破解内地香港区际平行诉讼之困局-从一起香港 高院审理的与内地信用证欺计案相关的平行诉讼案谈起], 1 CHINESE LAW. [中国律师] 64 (2017). <available only in Chinese>.

15. L. Zhao \& G. Xing, Forum shopping in international civil litigation [论国际民事诉讼中 的挑选法院], 2 J. Comp. L. [比较法研究] 34 (2002). < available only in Chinese>.

16. Zhao, supra note 15 , at 35.

17. Id. at 37-9.

18. XU Yingning vs. OUYANG Qingxiang, Qingcheng BPC, (2014) Qingcheng Fa Li Min Chu 7 [(2014) 清城法立民初字第7号]. <available only in Chinese>.

19. X. Chen, Paradox of the principle of prohibition of the denial of justice [禁止拒绝裁判悖 论之意蕴], 7 J. SOCIAL SCI. [社会科学] 115 (2018). < available only in Chinese>.

20. HCCH, Council on General Affairs and Policy (Mar. 2020), at 3, available at https:// assets.hcch.net/docs/d435cffc-65ce-4047-b603-ff63ed20591c.pdf.

21. See International Surrogacy Arrangements: Legal Regulation at the International LeVEL 236 (K. Trimmings \& P. Beaumont eds., 2013). 
22. G. Wang \& Y Yan, Recognition of legal parentage in transnational surrogacy arrangements [跨国代孕法定亲子关系承认问题研究], 1 J. HENAN U. ECON. \& L. [河南财经政法大学学 报] 165 (2019). <available only in Chinese>.

23. M. Greco, The Status of Children Arising from Inter-Country Surrogacy Arrangements 63 (2016).

24. Chen \& Xu vs. Meijai Co \&. Li Jie, Beijing Chaoyang BPC, (2018) Jing0105 Min Chu 2575 [(2018) 京0105民初2575号].<available only in Chinese>.

25. Y. Xu, Analysis on legalization of surrogacy [有条件代孕的合法化分析], 4 MedicinE \& JURISPRUDENCE [医学与法学] 53 (2018). <available only in Chinese>.

26. Li GAO vs. Meijia Co. \& Jie LI, Shandong Dezhou IPC, (2017) Lu14 Min Zhong 1863 [(2017) 鲁14民终1863号].<available only in Chinese>.

27. Shenzhen sears international business consulting co., LTD vs. Yan SUN, Guangzhou Shenzhen IPC, (2018) Yue 03 Min Zhong 9212 [(2018) 粤03民终9212号]. <available only in Chinese>.

28. X. Gao, Application of law in transnational surrogacy contracts [论跨国代孕合同的法 律适用] (2019) (unpublished master's thesis, Guangxi University at 18-9. (on file with author). <available only in Chinese>.

29. Jiang vs. Ren, Shanghai Pudong BPC, (2016) Hu0115 Min Chu 67451 [(2016) 沪0115民 初67451号]. <available only in Chinese>.

30. Article 3 of Specific Opinions of the Supreme People's Court on Handling the Issue of Bringing up Children in Divorce Cases.

31. E.g., Ukraine, Hungary, Belgium Venezuela, Germany and Spain use the "personal law of the child" (citizenship, place of living, closest connection and habitual residence) as one of the connecting factor to avoid the misunderstanding since there was no expression like 'parents' in the connecting factor and the involved 'child' can be easily identified.

32. For example, New Zealand, South Africa and Ireland use the "lex fori" as applicable law in definition of parenthood, which is more convenient for court and better to keep the consistency of domestic and international judgments.

33. $\mathrm{HCCH}$, spra note 20 , at 2.

34. J. Wang, The behaviour and characterization of evasion of law [法律规避行为及其裁判 方法], Peking U. L. J. 27 [中外法学] 629 (2015). <available only in Chinese>.

35. K. Trimmings \& P. Beaumont, International surrogacy Agreement: An Urgent Need for Legal Regulation at the International Level, in International Family Law 445 (A. Estin ed., 2016). See also Q. Yuan \& Y. Luo, The conflict of laws and solution of cross-border surrogacy, the experience of convention on the protection of children and international cooperation on the international adoption [跨境代孕中的法律冲突及其解决路径: 《跨国收养方面保护儿童及合作公约》的经验], 2 CHINESE REV. INT'L L. [国际法研究] 1267 (2019).

36. Yuan \& Luo, id. at 119-20. 
37. $\mathrm{HCCH}$, supra note 33 , at 3-4.

38. See Encyclopedia of Private International Law 209 (J. Basedow \& G. Rühl eds., 2017).

39. Id.

40. G. Wang, Public order of recognition of legal parentage in transnational surrogacy cases [论跨国代孕法定父母身份承认中的公共秩序], 1 WeSTERN L. REV. ChINA [西部法学评论] 128 (2018). < available only in Chinese>.

41. Yi Wang, The Paradox and Breakthrough of Public Order in Foreign Judicial RecognitionCentered On a Transnational Surrogacy Case [外国判决承认中公共秩序保留的怪圈与突 围: 以一起跨国代孕案件为中心], 1 STUD. L. \& Bus. [法商研究] 170-9 (2018). <available only in Chinese>.

42. P. Xiao \& J. Li, Same-Sex Marriage and Civil Union in Same-Sex Relationships, 16 USChina L. Rev. 228-9 (2019).

43. O. Khazova \& B. Mezmur, UN Committee on the rights of the child reflections on Family law issues in the jurisprudence of the CRC committee, in IntERnATIONAL SURVEY of Family LaW 322-326 (M. Brining ed., 2019).

44. HCCH, Apostille Section, available at https://www.hcch.net/en/instruments/conventions/ specialised-sections/apostille.

45. Wellenhofer, Familienrecht und IPR: Gewohnlicher Aufenthalt eines im Ausland von einer Leihmutter geborenen Kindes JuS 717 (2019). See also A. Dutta, Surrogacy in Germany, in Estern and Western Perspective on Surrogacy 35-48 (J. Scherpe \& C. Glynn eds., 2019). F. Klinkhammer, Surrogate motherhood under German national and international private law: A judicial Perspective, in Estern and Western Perspective on Surrogacy 49-58 (J. Scherpe \& C. Glynn eds., 2019).

46. A. Goldberg, Lesbian and Gay Parents and Their Children 4 (2010).

47. Han Zhao vs. Shan Jiang, Nanjing IPC, (2018) Su 01 Min Zhong 10499 [(2018) 苏01民 终10499号].<available only in Chinese>.

48. Id. at 6 .

49. GRCL art. 27. It provides: "The parents of a minor shall be his guardians, if the parents of a minor are dead or lack the competence to be his guardian, any of the following persons who has the competence to be a guardian shall act as his guardian in the following sequence: (1) Paternal or maternal grandparent; (2) Elder brother or sister; or (3) Any other individual or organization that is willing to bear the responsibility of guardianship, provided that the individual or organization shall obtain approval from the neighbours or village committee in the place of the minor's residence, or the civil affairs administrative department."

50. A.G.R. vs. D.R.H., No. FD-09-1838-07, slip op. at 2 (N.J. Super. Cr. Ch. Div Dec 23, 2009).

51. UDDOH vs. United Healthcare, No. 254 F.Supp.3d 424 (E.D.N.Y. 2017).

52. Shen Xinnan vs. Gulou Hospital, Jiangsu Yixing BPC, (2013) Yi Min Chu 2729. [(2013) 
宜民初字第2729号].Shen Xinnan vs. Gulou Hospital, Jiangsu Wuxi IPC, (2014) Xi Min Zhong 01235. [(2014) 锡民终字第01235号]. < available only in Chinese>.

53. TSJSC sentence no 1456, 27 July 2006.

54. Supreme People's Court, The determination of legal status of the children born under artificial insemination during marriage, (July 8, 1991).

55. Shen Xinnan vs. Gulou Hospital, Jiangsu Wuxi IPC, (2014) Xi Min Zhong 01235. [(2014) 锡民终字第01235号]. <available only in Chinese>.

56. The legal character of in vitro embryo: Inherit case of Jiangsu Yixing frozen embryos [体 外胚胎的法律性质及可继承性分析: 江苏宜兴冷冻胚胎继承案引起的思考], 2 J. HENAN U. ECON. \& L. [河南财经政法大学学报] 118 (2017). <available only in Chinese>.

57. Wang vs. Zhang on right of reproduction [王某某诉张某某生育选择权纠纷案], available at https://www.chinacourt.org/article/detail/2014/11/id/1491378.shtml. <available only in Chinese>.

58. Ying CHEN vs. Ronggeng LUO, Shanghai 01 IPC, (2015) Hu 01 Zhong Shao Min Zhong 56 [(2015) 沪一中少民终字第56号]. < available only in Chinese>. 